\title{
THE EFFECT OF COBALT AND IRON SALTS ON THE ANAEMIA OF PREMATURITY
}

\author{
BY \\ B. L. COLES and URSULA JAMES \\ From the Department of Paediatrics, Elizabeth Garrett Anderson Hospital (Royal Free Hospital Group), London
}

(RECEIVED FOR PUBLICATION NOVEMBER 3, 1953)

Premature infants tend to exhibit higher blood values at birth than full-term infants, but show a more rapid and prolonged fall in both haemoglobin and red cells and frequently develop anaemia which is maximal at about the third month (Parsons and Hawksley, 1933). Landé (1919), using a Sahli method (standard $17 \cdot 2$ g. equals $100 \%$ ) found average levels of 60 to $65 \%$ haemoglobin and average red cells of $3 \cdot 3 \mathrm{~m} . / \mathrm{c} . \mathrm{mm}$. at the third month. In many cases the count fell to $50 \%$. She quotes Knuckel who gave an average level of $47 \%$ at 3 months though the red cells were proportionately less reduced and averaged 4 million. Abt and Nagel (1932) divided their cases into those of six to seven months' gestation and those of eight months' gestation. The former reached the lowest point at eight to 12 weeks with average levels of $54 \%$ haemoglobin and 3.3 million red cells. The haemoglobin level of infants of eight months' gestation fell to $60 \%$ at 8 weeks, with 4.0 million red cells (16.9 g. haemoglobin equals $100 \%$, Newcomer). In another series (Merritt and Davidson, 1934) of untreated premature infants the haemoglobin fell from $21.7 \mathrm{~g}$. at birth to $11.0 \mathrm{~g}$. at 2 months of age. The red cells averaged 5.54 million at birth and fell to $\mathbf{3 . 9 1}$ million at 2 months. In a series of immature infants the counts fell from $23.0 \mathrm{~g}$. haemoglobin and $5 \cdot 81$ red cells to $11 \cdot 8 \mathrm{~g}$. and 4.04 red cells during the same period. In all cases the counts remained more or less stationary to 10 months of age, when the period of observation ceased. Herz (1928) considered values below $13 \mathrm{~g}$. at 2 to 4 months denoted anaemia. Of 103 premature infants investigated, 16 had values of 8 to $12 \mathrm{~g}$. at this age whereas only one full-term infant reached a value as low as $12 \mathrm{~g}$. Mackay (1935), investigating prematures of birth weight 3-4 lb., found a fall from $149.9 \%$ at birth to $73.4 \%$ at the tenth week. Infants of birth weight approximately $5 \mathrm{lb}$. showed a similar fall from $146.6 \%$ at birth to $76.0 \%$ at the fourteenth week. Most observers agree that the anaemia of prematurity is a self-limiting disease with spontaneous recovery after about the fourth month. In the series of Abt and Nagel (1932), infants of seven months' gestation reached values of $68 \%$ haemoglobin and 4.9 million red cells at 6 months, and infants of eight months' gestation, $69 \%$ haemoglobin and 4.9 million red cells at 6 months. Mackay's cases (1935) had risen to $81 \cdot 7 \%$ (birth weight $3-4 \mathrm{lb}$.) and $80 \cdot 8 \%$ (birth weight approximately $5 \mathrm{lb}$.) at 26 weeks of age. These cases were all untreated and form a contrast to those of Merritt and Davidson (1934), who reported no significant changes in the counts from the time of maximum anaemia to the tenth month. If the initial fall has been very marked, recovery is delayed and may be incomplete.

The pathogenesis of the anaemia of prematurity is obscure. Lichtenstein (1921) found a negative iron balance in four premature infants not receiving additional iron, but this work was not confirmed by Snelling (1933). Josephs (1936) divided the anaemia of prematurity into three stages. The early physiological anaemia during the first two months, in which there is no response to haemopoietic agents and the reticulocytes are low, constitutes the first stage. The second stage is marked by a gradual rise in the red cells, the haemoglobin remaining stationary. At this stage hypochromia may develop and the response to iron is usually good. He considered a mild iron deficiency was of importance in the development of this phase. The third phase is identical with the hypochromic anaemia of full-term infants but is more marked. He believed that the iron stores of the premature infant are deficient only in relation to the more rapid rate of growth. This view is also held by Mackay (1935). Josephs also thought that iron deficiency does not occur before the third month except in cases of loss as in haemorrhage or excessive haemolysis, but that after the third month iron deficiency becomes increasingly important. He concluded that in premature infants 
there is either a failure to utilize iron or an inability to synthesize haemoglobin sufficiently rapidly. He also emphasized the high infection rate in premature infants with particular reference to syphilis as a cause of premature birth, and of consequent aggravation of existing anaemia. Abt (1935) also reviewed the possible causes of anaemia in premature infants and suggested that the smaller total blood volume at birth results in a poor supply of iron from endogenous sources. Iron supplies are exhausted between the third and sixth months owing to the rapid rate of growth and an iron deficiency is thus produced. $\mathrm{He}$ also suggested a functional incapacity of the haemopoietic system. This possibility was confirmed by marrow investigations (Lichtenstein and Nordenson, 1939). The bone marrow of 25 premature infants showed a marrow which was immature though hyperplastic, and maturation did not proceed along normal lines. This picture was correlated with signs of immaturity in the peripheral blood and with an anaemia which was maximal at the third month. The most severe anaemia coincided with the greatest immaturity of the marrow. After the third month the marrow picture improved considerably but some degree of immaturity persisted throughout the first year. These findings compare with the hyperplastic yet insufficient marrow found in other anaemias. Landé (1919) examined the marrow in 10 premature infants without finding any cause for their anaemia though she mentioned the deficiency of granulocytes which is associated with the poor resistance to infection of these infants.

The response to treatment of the anaemia of prematurity is disappointing. Intramuscular blood has been tried with unsatisfactory results (Landé, 1919; Mackay, 1935). Liver, either alone or in combination with a hog's stomach preparation, had no beneficial effect (Abt and Nagel, 1932). Iron and ammonium citrate with or without liver extract has been found to minimize the severity of the anaemia but not to prevent it entirely (Abt and Nagel, 1932; Merritt and Davidson, 1934). Merritt and Davidson state that observers are agreed that anaemia in premature infants cannot be completely prevented and that those reporting success with iron have always used large doses. Various remedies employed without success include exposure to fresh air, dietary methods with substitution of fruit and vegetables for an exclusively milk diet, vitamin $B$, hog's stomach, and copper alone or with iron. The diversity of treatment investigated indicates that no entirely satisfactory method has yet been found. The best is probably iron in some form with transfusion reserved for the most severe cases. The benefits of this, however, tend to be transitory and repeated transfusions are often necessary. Although spontaneous recovery from the anaemia is usual and pallor is often the only symptom, the development of any anaemia in infants already handicapped by prematurity may be serious. This is chiefly due to the increased risk of infection in anaemic children, and premature infants are already particularly prone to infections. Blood transfusion is a skilled procedure in these small infants and is not entirely free from risk, and an easily administered and well tolerated drug effective in the prophylaxis and treatment of the anaemia of prematurity would be of some clinical importance.

The blood picture in this anaemia is of normocytic normochromic type with a low reticulocyte count, and in these features it shows a marked similarity to the anaemia associated with infection. It has been suggested by Wintrobe, Grinstein, Dubash, Humphreys, Ashenbrucker and Worth (1947) that cobalt may be needed in the synthesis of haemoglobin in the anaemia of sepsis, and Vaughan (1948) referred to this in a paper on the anaemia of sepsis and trauma, and suggested cobalt as a possible treatment of anaemias resulting from infection. It was because of the similarity between the anaemia of sepsis and that of prematurity that we decided to try the effect of cobalt in premature infants.

There is a considerable literature on the experimental use of cobalt in producing polycythaemia both in normal and anaemic animals. Orten, Underhill, Mugrage and Lewis (1932), Orten (1936) and Stanley, Hopps and Hellbaum (1946), studied its effect on rats, Frost, Elvehjem and Hart (1941) on dogs, and Davis, McCullough and Rigdon (1945) on ducks. Cartwright (1947) gave a comprehensive review of the experimental work. In treated animals the haemoglobin and red cell counts both showed considerable increases over values for normal controls. Wintrobe et al. (1947) and Gubler, Cartwright and Wintrobe (1950) studied the effect of cobalt on rats made anaemic by the production of turpentine abscesses. They found that animals to which cobalt was given in addition to turpentine not only failed to develop anaemia but actually became polycythaemic. In rats already made anaemic the administration of cobalt rectified the anaemia. Rats treated with turpentine had low plasma iron levels and raised erythrocyte protoporphyrins, results also found in patients with anaemia associated with sepsis. The blood iron level of rats treated with turpentine and of those receiving turpentine and cobalt showed highly significant differences, and it is concluded that cobalt favourably influences the utilization of iron for haemoglobin synthesis. All the rats in Gubler's experiments were receiving iron 
at the time, and increased absorption of iron was not demonstrated after cobalt treatment, thus suggesting that cobalt favours increased utilization of available iron. This view is supported by the work of Kato and Iob (1940) on the influence of cobalt on iron storage. These authors found that animals receiving large doses of iron over long periods stored iron in the spleen and to a lesser extent in the bone marrow. When cobalt was given together with iron, no iron was found in these organs, but the total iron content of the blood was raised $24-58 \%$ above control values. This bears out the suggestion that cobalt enables iron to be more completely utilized for haemopoiesis than when iron is given alone. In animals there is a slight reticulocytosis maximal about the fourth day with a secondary rise reaching a peak on the twentieth to twenty-fourth day (Orten, 1936). These responses were observed both in young and in adult animals. In ducks the bone marrow shows a hyperplasia of the erythroid elements up to the fourteenth day, but by the nineteenth day there is evidence of hypoplasia of the erythroid series (Davis et al., 1945). It is possible that the initial rise in peripheral blood levels is due to erythropoietic stimulation of the marrow but that the maintenance of polycythaemia may in part be due to a depressed rate of blood destruction. Kato and Iob also studied the marrow during cobalt treatment and found that at the height of polycythaemia there was a distinct hyperplasia of all marrow elements but especially of the erythroid series. They did not note any evidence of toxicity to the marrow.

Experience of the effect of cobalt on weight and appetite seems to vary. Wintrobe et al. (1947) found that cobalt impaired weight gain more than turpentine injections in a series of rats, though both failed to gain as well as control animals. They thought that failure might be associated with anorexia. Orten $e t$ al. (1932) also found that rats on cobalt gained less than the controls. In ducks, however, there was no difference between treated cases and controls (Davis et al. 1945). Orten and Bucciero (1948) found that treated animals ate more per $100 \mathrm{~g}$. body weight than control animals. Milk contains extremely small amounts of cobalt (Frost et al., 1941); therefore if a true cobalt deficiency exists in man, young infants would be liable to such a deficiency. Frost and his co-workers found that about half the dogs investigated, which were fed on an exclusive milk-iron-copper diet, showed evidence of cobalt deficiency in that the blood responded to doses as small as $0.1 \mathrm{mg}$. daily. It is an established fact that sheep and cattle fed on pastures where the soil is deficient in cobalt develop a wasting disease in which anaemia is a prominent feature (Gall, Smith, Becker, Stark and Loosli, 1949), but so far there are no conclusive reports of cobalt deficiency in man.

Therapeutic reports of cobalt in the treatment of anaemia in man are few and there is no reference to its use in premature infants. Waltner (1930) first discussed its uses in the anaemia of childhood although it had already been tried by Antal in 1894 as an antidote to cyanide poisoning, and a cobaltarsenical preparation had been used as a general tonic. Waltner treated 21 children with secondary anaemia, with 14 favourable results. After four to five weeks the red cells had risen by $32.5 \%$ from an average starting point of 3.36 million/c.mm. He found that cobalt had little effect on the haemoglobin and advised that it should be given in combination with iron. He also treated 57 children with cobalt used as a tonic, and noted beneficial effects on the appetite and weight in 31 , who averaged a weekly gain of 250 g.; 26 failed to respond. Baxter (1939) gave $2-30 \mathrm{mg}$. of cobaltous chloride daily to eight patients with hypochromic anaemia. He obtained an average daily rise of 18,800 red cells and $0.11 \%$ haemoglobin, but considered cobalt inferior to iron and of no use in hypochromic anaemia. Three cases developed anorexia, two nausea, one vomiting, one pruritis and one urticaria, a high incidence of toxic manifestations. Cronin (1939) treated one case of lymphatic leukaemia and one case of hypochromic anaemia with $30 \mathrm{mg}$. daily. There was no haematological response in either case. Kato (1937) reported a series of infants with haemoglobin levels below $11 \mathrm{~g}$. They received iron and ammonium citrate, $0.5 \mathrm{~g}$. daily, and $25-50 \mathrm{mg}$. cobalt sulphate was given to 37 infants who failed to respond to iron. Eighteen received cobalt and iron from the start. Seventy-six per cent. of those treated showed satisfactory responses, the haemoglobin, red cells and haematocrit increased in parallel, and the majority of cases made the best progress within two weeks of starting treatment. The average weekly rise in red cells was 250,000 , in haemoglobin $0 \cdot 6-0.9 \mathrm{~g}$. $\%$, and in haematocrit readings $1-1 \cdot 5 \%$. There were no toxic effects, Caussade, Franck and PetitdantMonniot (1947) used cobaltous chloride, $10 \mathrm{mg}$. daily, on five infants, and $20 \mathrm{mg}$. daily on eight children aged from 2 to 7 years. They obtained satisfactory results in all but two infants in whom treatment was interrupted because of infection. The general condition improved and the infants had increased vigour following treatment.

The effect of cobalt on the anaemia of infection has been studied by Robinson, James and Kark (1949) who treated nine patients with chronic osteomyelitis or soft tissue suppuration. They used 
cobaltous chloride in doses of $20-60 \mathrm{mg}$. daily for two to 11 weeks. Reticulocyte responses occurred as early as the fourth day and were maintained throughout treatment. In all cases a return to normal blood values was obtained. Two patients had slight anorexia. Cobalt has also produced haematological responses in subjects without anaemia (Berk, Burchenal and Castle, 1949). Eight patients received $100 \mathrm{mg}$. cobaltous chloride daily and reticulocyte responses occurred in six cases. Dosage was then increased to $200 \mathrm{mg}$. daily and the two remaining patients developed a reticulocytosis. The others reached a higher peak than they had attained on the smaller dose. All cases showed moderate increases in haemoglobin, red cells, and haematocrit readings. Two patients received $300 \mathrm{mg}$. daily with higher responses than the first eight, and one case required venesection after treatment. Increasing doses, up to $400 \mathrm{mg}$. thrice daily, produced anorexia in one case after six weeks, and severe nausea and vomiting after two weeks in the second case. Six cases of pernicious anaemia in remission developed symptoms and treatment had to be stopped. Of 32 anaemic patients reported in the same paper, five with chronic sepsis showed a good response. One of two patients with carcinoma of the stomach, and a case of Cooley's anaemia, also responded. Three of 10 patients with lymphoma gave a doubtful response; there was no effect on anaemia associated with cirrhosis of the liver or chronic renal disease. Apart from mild alimentary symptoms, two patients developed precordial pain with evidence of myocardial infarction. All symptoms were relieved after cobalt was stopped. Because of its similarity to the anaemia of sepsis in which cobalt had proved of some value, Shen and Homburger (1951) treated 16 patients with anaemia associated with advanced cancer with cobaltous chloride, 60-240 mg. daily. Nine patients had a reticulocyte response and three showed elevation of the blood count to normal levels. Two failed to respond at all, two died before any rise could be expected although they had a reticulocytosis, and two were unable to tolerate the drug. The authors noted a high incidence of toxic reactions including nausea, vomiting, anorexia, muscle pains and angina. Even in patients with a satisfactory haematological response, the clinical condition remained unsatisfactory and patients continued to complain of depression and apathy in spite of normal blood levels. The only series where bone marrow studies have been used to confirm the peripheral blood findings is that of Virdis (1952) who treated nine children aged 1 to 3 years with alimentary anaemia or anaemia associated with infection. One case of macrocytic anaemia failed to respond but the others all showed increases in red cells, though the haemoglobin remained relatively low. He recommended the simultaneous administration of iron to secure corresponding rises in haemoglobin. In all but three cases marrow puncture showed stimulation of erythropoiesis and a fall in the myeloid-erythroid ratio. Cobaltous chloride was used in daily doses of $15-20 \mathrm{mg}$. by mouth or $1 \mathrm{mg}$. intramuscularly.

\section{Present Investigation}

Premature infants born at four maternity units took part in this investigation, which covered a period of 18 months. Cases from three units were used for the whole time and those from the fourth for the first year only. In all, 126 consecutive infants were investigated and 83 were followed up for six months or longer. Four further infants were excluded from the series, one on account of severe haemorrhage from the cord and three because of death in the neonatal period. Red cell counts were made with an improved Neubauer counting chamber using normal saline and methyl violet as a diluting agent, and the haemoglobin was estimated by the Sahli method using a standard of $14 \mathrm{~g}$. haemoglobin equals $100 \%$. In the neonatal period the blood-acid mixture was allowed to stand an hour before readings were made, as Whitby and Britton (1950) point out that foetal haemoglobin takes longer to convert to acid haematin than the adult type, and falsely low results may be obtained if this is not taken into account. The same counting chamber, standard and glassware were used throughout the investigation to obtain comparable results, and all blood was taken and examined by one observer (B.L.C.). Blood was obtained in all cases by heel puncture.

The cases were divided at random into four groups as follows: Group I acted as controls. Group II received cobalt sulphate, $10 \mathrm{mg}$. daily by mouth, from the first to the twelfth days of life inclusive. Group III received cobalt sulphate, $20 \mathrm{mg}$. daily by mouth, from four to eight weeks. Group IV received $20 \mathrm{mg}$. as above together with gr. $4 \frac{1}{2}$ of ferrous sulphate daily from four to eight weeks.

The cobalt sulphate used was the B.D.H. analar salt which is freely soluble in water and practically tasteless. The iron mixture was prepared according to Mackay's formula, and was given in three divided doses.

Blood counts were made in all cases at birth, 1 week, 2 weeks, 1 month, and at monthly intervals to 6 months. After 6 months the blood was examined at 9 months, and again at 1 year in those cases still attending. In the early stages of the investigation we were anxious to ascertain if the administration 
of cobalt from one to 12 days influenced the physiological fall during the first weeks of life and counts were therefore made on the fourth, eighth and twelfth days of life in 20 cases receiving cobalt and 18 controls. This was discontinued owing to the negative results. We also wished to ensure that a month's continued cobalt from four to eight weeks did not produce polycythaemia. Eighteen cases on therapy from four to eight weeks, 14 controls and 12 Group II cases had counts at 6 weeks of age. These counts lay midway between those at 1 month and 2 months in the majority of cases and the results are therefore not included in our table.

We adopted an arbitrary level at which further treatment was instituted if anaemia developed during the course of the investigation. Cobalt sulphate, $20 \mathrm{mg}$. daily, was given to any infant whose red cell count fell below $2.5 \mathrm{~m}$./c.mm. if the haemoglobin was below $70 \%$ at that time, and ferrous sulphate, gr. $4 \frac{1}{2}$, was given to infants with haemoglobin below $70 \%$, and infants of 6 months with haemoglobin below $75 \%$ for two consecutive months were also given iron in order to prevent a severe iron deficiency anaemia. In cases requiring additional iron therapy at 6 months the blood was examined monthly until therapy ceased and satisfactory blood levels were obtained.

All infants were either breast fed or received dried or evaporated milk made up 20 calories to the ounce. Vitamins A, D and C were started as soon as feeding was satisfactorily established, usually at about the tenth day, and solids were introduced in all cases between $3 \frac{1}{2}$ and 5 months. Where possible the infants attended special follow-up clinics attached to the maternity unit, but where distance or domestic duties made this impossible they were visited at home. Records of weight and clinical progress were made at each visit.

\section{Results}

During the first 12 days of life 20 cases receiving cobalt and 18 controls had blood counts on the fourth, eighth and twelfth day. The average fall of haemoglobin and red cells below birth level on each day of bleeding are shown in Table 1. The infants receiving cobalt showed a less pronounced fall in both haemoglobin and red cells, but the differences are not marked. The effect of the early administration of cobalt on the later counts, i.e., from one month onwards, will be discussed later, but it appears that cobalt has little effect in modifying the fall during the first two weeks.

The results of counts from birth to 1 year have been expressed in two ways. All cases have been grouped according to the treatment they received and in addition divided into those of birth weight $4 \frac{1}{2}-5 \frac{1}{2} \mathrm{lb}$. and those of birth weight under $4 \frac{1}{2} \mathrm{lb}$. These results are shown in Tables 2 and 3. Tables 4 and 5 show the same cases rearranged according to the gestation period. Cases of eight to nine months' gestation are shown in Table 4, and cases of six to eight months' gestation in Table 5. It was felt that this would give a more accurate picture of the results as the smallest infants in our series were not always the most premature by dates or in behaviour. Once an infant required additional therapy its data were removed from these tables and findings in such cases are expressed separately. For statistical purposes all cases were analysed together irrespective of birth weight to enable larger numbers to be used for comparison, and the statistical analysis only extends over the first six months of life. These analyses are shown in Tables 6 and 7. The study of the last six tables shows surprisingly little difference in the values for controls between the two birth weight groups. When the cases are arranged according to gestation period, however, there is a marked tendency for those of six to eight months' gestation to develop low haemoglobin values after the age of 4 months, compared with the infants of 8 to 9 months' although the red cell counts remain comparable in both groups. In the treated cases the figures for both birth weight groups and both gestation groups are extremely close and initial weight appears to play little part in the response to treatment. The statistical analysis shows that infants receiving cobalt from one to 12 days (Group II) had slightly higher average haemoglobin and red cell counts than the controls (Group I). The difference

TABLE 1

AVERAGE FALL OF HAEMOGLOBIN AND RED BLOOD CELLS BELOW BIRTH LEVELS DURING FIRST 12 DAYS

\begin{tabular}{|c|c|c|c|c|c|c|c|c|}
\hline \multirow[b]{2}{*}{ Group } & & \multicolumn{2}{|c|}{ 4th Day } & \multicolumn{2}{|c|}{ 8th Day } & \multicolumn{2}{|c|}{ 12th Day } & \multirow[b]{2}{*}{ No. of Cases } \\
\hline & & Hb. $(\%)$ & R.B.C. (m.) & Hb. (\%) & R.B.C. (m.) & Hb. (\%) & R.B.C. (m.) & \\
\hline I .. & .. & $6 \cdot 55$ & 0.40 & $16 \cdot 77$ & 0.82 & $23 \cdot 71$ & $1 \cdot 26$ & 18 \\
\hline II .. & .. & $5 \cdot 85$ & 0.42 & $10 \cdot 95$ & 0.80 & $22 \cdot 00$ & 0.88 & 20 \\
\hline
\end{tabular}


in haemoglobin content at 2 months and four of the six differences in average red cell counts, those at 1 , 2, 4 and 5 months attained statistical significance. Up to the age of 6 months control values for both haemoglobin and red cells are well below those for either Group III or Group IV cases, whether cases are arranged by birth weight or by gestation period. In view of the small effect of the early administration of cobalt the data for this group of infants have been amalgamated with those for the control group to give a more dependable standard against which to assess any effect of giving cobalt from one to two months. Infants who received cobalt from 1 to 2 months (Groups III and IV combined) had a significantly higher average haemoglobin content and red cell count at each examination from 2 months onwards than Groups I and II combined. Infants in Group IV had statistically significant higher haemoglobin contents from 4 to 6 months than Group III cases who also received cobalt but no iron. At this stage iron deficiency becomes important in the development of anaemia in premature infants, and these results were to be expected. The red cells appear unaffected by iron. Counts at 9 months and 1 year have been included in our tables as a matter of interest, but the numbers are too small to be of any value for statistical purposes. Those control cases which had reached nine months without developing anaemia appeared by this time to have satisfactory blood levels and to have reached the values of the treated cases.

The counts in three cases fell to the values set as

TABLE 2

AVERAGE HAEMOGLOBIN CONTENT AND RED CELL COUNTS FROM BIRTH TO 1 YEAR IN INFANTS OF BIRTH WEIGHT OVER $4 \frac{1}{\mathrm{l}} \mathrm{lb}$.

\begin{tabular}{|c|c|c|c|c|c|c|c|c|c|}
\hline \multirow{2}{*}{\multicolumn{2}{|c|}{ Age and Group }} & & \multicolumn{2}{|c|}{ Average Counts } & \multicolumn{2}{|c|}{ Maximum Counts } & \multicolumn{2}{|c|}{ Minimum Counts } & \multirow[b]{2}{*}{ No. of Cases } \\
\hline & & & Hb. (\%) & R.B.C. (m.) & Hb. (\%) & R.B.C. (m.) & Hb. (\%) & R.B.C. (m.) & \\
\hline Birth & $\begin{array}{c}\text { I } \\
\text { II } \\
\text { IV }\end{array}$ & $\begin{array}{l}\because \\
\therefore\end{array}$ & $\begin{array}{l}21 \cdot 8 \\
21 \cdot 7 \\
20 \cdot 7 \\
21 \cdot 4\end{array}$ & $\begin{array}{l}5 \cdot 79 \\
6.03 \\
5.90 \\
6.07\end{array}$ & $\begin{array}{l}24 \cdot 9 \\
25 \cdot 2 \\
25 \cdot 2 \\
25 \cdot 2\end{array}$ & $\begin{array}{l}7 \cdot 20 \\
6 \cdot 74 \\
7 \cdot 20 \\
7 \cdot 12\end{array}$ & $\begin{array}{l}15.7 \\
15.7 \\
14.3 \\
16.8\end{array}$ & $\begin{array}{l}4 \cdot 58 \\
5 \cdot 26 \\
4 \cdot 86 \\
5 \cdot 50\end{array}$ & $\begin{array}{l}31 \\
16 \\
14 \\
12\end{array}$ \\
\hline 1 month & $\begin{array}{l}\text { I } \\
\text { II } \\
\text { II }\end{array}$ & $\begin{array}{l}. \\
\therefore \\
.\end{array}$ & $\begin{array}{l}13 \cdot 4 \\
14 \cdot 1 \\
13 \cdot 3 \\
15 \cdot 2\end{array}$ & $\begin{array}{l}4 \cdot 00 \\
4 \cdot 53 \\
4 \cdot 04 \\
4 \cdot 12\end{array}$ & $\begin{array}{l}17 \cdot 6 \\
18.9 \\
16.0 \\
18 \cdot 7\end{array}$ & $\begin{array}{l}5.50 \\
5.74 \\
5.76 \\
4.88\end{array}$ & $\begin{array}{r}10.6 \\
10.9 \\
8.8 \\
12.5\end{array}$ & $\begin{array}{l}2 \cdot 92 \\
2 \cdot 59 \\
2.62 \\
3 \cdot 16\end{array}$ & $\begin{array}{l}18 \\
14 \\
14 \\
12\end{array}$ \\
\hline 2 months & $\begin{array}{l}\text { I } \\
\text { II } \\
\text { IIV }\end{array}$ & $\begin{array}{l}. \\
. \\
. .\end{array}$ & $\begin{array}{l}10.8 \\
11.9 \\
12.5 \\
12.9\end{array}$ & $\begin{array}{l}3 \cdot 55 \\
3 \cdot 82 \\
4 \cdot 13 \\
4 \cdot 30\end{array}$ & $\begin{array}{l}12 \cdot 6 \\
16 \cdot 1 \\
17 \cdot 5 \\
16 \cdot 0\end{array}$ & $\begin{array}{l}4 \cdot 36 \\
4 \cdot 82 \\
5 \cdot 32 \\
5 \cdot 90\end{array}$ & $\begin{array}{r}9.4 \\
9.2 \\
9.8 \\
10.8\end{array}$ & $\begin{array}{l}2 \cdot 64 \\
3 \cdot 28 \\
3 \cdot 52 \\
3 \cdot 32\end{array}$ & $\begin{array}{l}15 \\
13 \\
14 \\
12\end{array}$ \\
\hline 3 months & $\begin{array}{c}\text { I } \\
\text { III } \\
\text { IV }\end{array}$ & $\begin{array}{l}. . \\
. \\
.\end{array}$ & $\begin{array}{l}10.8 \\
10.8 \\
11.8 \\
12.3\end{array}$ & $\begin{array}{l}3 \cdot 75 \\
3 \cdot 71 \\
4 \cdot 50 \\
4 \cdot 41\end{array}$ & $\begin{array}{l}12 \cdot 6 \\
14 \cdot 8 \\
14 \cdot 0 \\
14 \cdot 1\end{array}$ & $\begin{array}{l}4 \cdot 48 \\
4 \cdot 34 \\
5 \cdot 56 \\
5 \cdot 70\end{array}$ & $\begin{array}{r}9.8 \\
9.7 \\
9.0 \\
11.2\end{array}$ & $\begin{array}{l}2 \cdot 84 \\
3 \cdot 20 \\
3 \cdot 60 \\
3 \cdot 72\end{array}$ & $\begin{array}{l}13 \\
11 \\
14 \\
10\end{array}$ \\
\hline 4 months & $\begin{array}{r}\text { I } \\
\text { II } \\
\text { III }\end{array}$ & $\begin{array}{l}. \\
. \\
.\end{array}$ & $\begin{array}{l}10.8 \\
11.8 \\
11.6 \\
12.7\end{array}$ & $\begin{array}{l}3 \cdot 70 \\
4 \cdot 30 \\
3 \cdot 36 \\
4 \cdot 31\end{array}$ & $\begin{array}{l}12.6 \\
15.4 \\
13.0 \\
14.6\end{array}$ & $\begin{array}{l}4 \cdot 70 \\
5 \cdot 02 \\
5 \cdot 48 \\
5 \cdot 24\end{array}$ & $\begin{array}{r}8 \cdot 4 \\
9 \cdot 2 \\
7 \cdot 4 \\
12 \cdot 0\end{array}$ & $\begin{array}{l}2.59 \\
3.44 \\
3.65 \\
3.66\end{array}$ & $\begin{array}{l}13 \\
11 \\
14 \\
11\end{array}$ \\
\hline 5 months & $\begin{array}{r}\text { I } \\
\text { II } \\
\text { IV }\end{array}$ & $\begin{array}{l}. . \\
. \\
. .\end{array}$ & $\begin{array}{l}11 \cdot 3 \\
12 \cdot 0 \\
11 \cdot 8 \\
12 \cdot 0\end{array}$ & $\begin{array}{l}4 \cdot 04 \\
4 \cdot 46 \\
4 \cdot 50 \\
4 \cdot 21\end{array}$ & $\begin{array}{l}13 \cdot 2 \\
15.0 \\
13.9 \\
13.7\end{array}$ & $\begin{array}{l}4.98 \\
4.92 \\
5.50 \\
4.74\end{array}$ & $\begin{array}{r}9.8 \\
9.7 \\
9.9 \\
11.5\end{array}$ & $\begin{array}{l}3.08 \\
3.92 \\
3.95 \\
3.58\end{array}$ & $\begin{array}{r}11 \\
11 \\
12 \\
9\end{array}$ \\
\hline 6 months & $\begin{array}{l}\text { I } \\
\text { III } \\
\text { IV }\end{array}$ & $\begin{array}{l}. \\
\therefore \\
\therefore\end{array}$ & $\begin{array}{l}11.2 \\
11.6 \\
11.9 \\
12.7\end{array}$ & $\begin{array}{l}4 \cdot 15 \\
4 \cdot 35 \\
4 \cdot 44 \\
4 \cdot 60\end{array}$ & $\begin{array}{l}12 \cdot 7 \\
14 \cdot 0 \\
13.9 \\
14.7\end{array}$ & $\begin{array}{l}5 \cdot 26 \\
4 \cdot 79 \\
5 \cdot 36 \\
5 \cdot 22\end{array}$ & $\begin{array}{r}8 \cdot 0 \\
9.2 \\
9.8 \\
10.6\end{array}$ & $\begin{array}{l}3 \cdot 48 \\
3 \cdot 66 \\
4 \cdot 04 \\
3 \cdot 89\end{array}$ & $\begin{array}{r}11 \\
9 \\
12 \\
8\end{array}$ \\
\hline 9 months & $\begin{array}{l}\text { I } \\
\text { II } \\
\text { IIV }\end{array}$ & $\begin{array}{l}. \\
. \\
.\end{array}$ & $\begin{array}{l}12 \cdot 0 \\
12 \cdot 0 \\
12 \cdot 9 \\
12 \cdot 3\end{array}$ & $\begin{array}{l}4 \cdot 41 \\
4 \cdot 43 \\
4 \cdot 53 \\
4 \cdot 49\end{array}$ & $\begin{array}{l}14 \cdot 0 \\
13 \cdot 6 \\
14 \cdot 1 \\
12 \cdot 9\end{array}$ & $\begin{array}{l}5.62 \\
4 \cdot 88 \\
5.56 \\
5 \cdot 26\end{array}$ & $\begin{array}{r}8.4 \\
10.5 \\
11 \cdot 5 \\
11.9\end{array}$ & $\begin{array}{l}3.61 \\
3.69 \\
3.68 \\
3.98\end{array}$ & $\begin{array}{l}7 \\
6 \\
8 \\
4\end{array}$ \\
\hline 1 year & $\begin{array}{r}\text { I } \\
\text { II } \\
\text { II }\end{array}$ & $\begin{array}{l}. \\
. \\
.\end{array}$ & $\begin{array}{l}12.0 \\
12.7 \\
11.9 \\
12.6\end{array}$ & $\begin{array}{l}4 \cdot 15 \\
4 \cdot 06 \\
4 \cdot 51 \\
4 \cdot 04\end{array}$ & $\begin{array}{l}14.0 \\
13.4 \\
12.6 \\
13.0\end{array}$ & $\begin{array}{l}5 \cdot 00 \\
4 \cdot 15 \\
4 \cdot 77 \\
4 \cdot 38\end{array}$ & $\begin{array}{l}11 \cdot 2 \\
11 \cdot 5 \\
11 \cdot 5 \\
12.0\end{array}$ & $\begin{array}{l}3 \cdot 40 \\
3 \cdot 97 \\
4 \cdot 23 \\
3 \cdot 41\end{array}$ & $\begin{array}{l}4 \\
3 \\
5 \\
3\end{array}$ \\
\hline
\end{tabular}

Group I. Controls.

II. Cob. Sulph. $10 \mathrm{mg} ., 1-12$ days.
III. Cob. Sulph. 20 mg., 4-8 weeks.

IV. Cob. Sulph. 20 mg. plus Fe. Sulph g. $4 \frac{1}{2}, 4-8$ weeks. 
indications for additional cobalt therapy. All these were controls. A fourth control (P.S.) with a count of $66 \%$ haemoglobin and $3.08 \mathrm{~m}$./c.mm. red cells at 5 months had severe symptoms of anaemia with anorexia, lassitude, and extreme pallor, and it was decided to treat this infant, although the count had not reached our minimum criteria. The initial counts and response to treatment of these four cases are shown in Table 8. All infants responded satisfactorily to treatment but the two cases which did not require therapy until the age of 5 months were obviously suffering from coincidental iron deficiency, and required iron as well as cobalt before satisfactory haemoglobin levels could be reached although the red cells responded to cobalt alone.

In 14 cases the haemoglobin fell to levels requiring iron therapy. These were divided as follows: Group I, 8 cases; Group II, 3 cases; Group III, 3 cases; Group IV, nil cases.

Details of these cases are shown in Table 10.
The youngest infant requiring iron was 4 months, and eight of the 14 cases required treatment at 6 months. This appeared to be the most common time for an iron deficiency anaemia to become manifest in our series. Two of the three Group III cases requiring iron were twins, and six of the total 14 cases requiring iron were twins.

No case receiving iron and cobalt from 4 to 8 weeks required additional iron therapy. The numbers in the various groups were approximately the same and we feel it is of some significance that all infants requiring additional cobalt were controls and that $57 \%$ of the cases requiring additional iron were also controls. The role of cobalt in favouring iron utilization has been mentioned before and will be reviewed in relation to these results in the discussion.

It has been shown (Mackay, 1931) that artificially fed infants are more prone to anaemia than those receiving breast milk, and that if anaemia develops

TABLE 3

AVERAGE HAEMOGLOBIN CONTENT AND RED CELL COUNTS FROM BIRTH TO 1 YEAR IN INFANTS OF BIRTH WEIGHT UNDER 4I LB.

\begin{tabular}{|c|c|c|c|c|c|c|c|c|c|}
\hline \multirow[b]{2}{*}{ Age and } & \multirow{2}{*}{\multicolumn{2}{|c|}{ Group }} & \multicolumn{2}{|c|}{ Average Counts } & \multicolumn{2}{|c|}{ Maximum Counts } & \multicolumn{2}{|c|}{ Minimum Counts } & \multirow[b]{2}{*}{ No. of Cases } \\
\hline & & & Hb. (\%) & R.B.C. (m.) & Hb. (\%) & R.B.C. (m.) & Hb. (\%) & R.B.C. (m.) & \\
\hline Birth & $\begin{array}{r}\text { I } \\
\text { II } \\
\text { III }\end{array}$ & $\begin{array}{l}\ldots \\
\cdots \\
\cdots\end{array}$ & $\begin{array}{l}21 \cdot 3 \\
20 \cdot 7 \\
20 \cdot 4 \\
21 \cdot 7\end{array}$ & $\begin{array}{l}5 \cdot 70 \\
5 \cdot 52 \\
5 \cdot 45 \\
5 \cdot 47\end{array}$ & $\begin{array}{l}24 \cdot 9 \\
22 \cdot 4 \\
25 \cdot 2 \\
24 \cdot 5\end{array}$ & $\begin{array}{l}7 \cdot 38 \\
6 \cdot 58 \\
6 \cdot 32 \\
6 \cdot 50\end{array}$ & $\begin{array}{l}15 \cdot 3 \\
15 \cdot 7 \\
15 \cdot 4 \\
17 \cdot 5\end{array}$ & $\begin{array}{l}4 \cdot 10 \\
5 \cdot 12 \\
3 \cdot 92 \\
4 \cdot 60\end{array}$ & $\begin{array}{r}22 \\
6 \\
15 \\
10\end{array}$ \\
\hline 1 month & $\begin{array}{r}\text { I } \\
\text { III } \\
\text { IV }\end{array}$ & $\begin{array}{l}\ldots \\
\cdots \\
\cdots\end{array}$ & $\begin{array}{l}14 \cdot 6 \\
13 \cdot 3 \\
14 \cdot 7 \\
14 \cdot 7\end{array}$ & $\begin{array}{l}3 \cdot 82 \\
4 \cdot 16 \\
3 \cdot 99 \\
4 \cdot 02\end{array}$ & $\begin{array}{l}19 \cdot 2 \\
15 \cdot 7 \\
19 \cdot 6 \\
17 \cdot 2\end{array}$ & $\begin{array}{l}4 \cdot 96 \\
4 \cdot 68 \\
5 \cdot 36 \\
5 \cdot 42\end{array}$ & $\begin{array}{l}11 \cdot 1 \\
11 \cdot 9 \\
10.9 \\
11 \cdot 2\end{array}$ & $\begin{array}{l}2 \cdot 90 \\
3 \cdot 52 \\
2 \cdot 84 \\
2 \cdot 35\end{array}$ & $\begin{array}{r}17 \\
6 \\
15 \\
10\end{array}$ \\
\hline 2 months & $\begin{array}{r}\text { I } \\
\text { III } \\
\text { IV }\end{array}$ & $\begin{array}{l}\ldots \\
\cdots \\
.\end{array}$ & $\begin{array}{l}10.6 \\
11.3 \\
12.7 \\
11.8\end{array}$ & $\begin{array}{l}3 \cdot 03 \\
3 \cdot 71 \\
4 \cdot 14 \\
3 \cdot 72\end{array}$ & $\begin{array}{l}13 \cdot 2 \\
13 \cdot 0 \\
15 \cdot 7 \\
12.6\end{array}$ & $\begin{array}{l}3 \cdot 98 \\
4 \cdot 38 \\
5 \cdot 72 \\
4 \cdot 92\end{array}$ & $\begin{array}{r}8 \cdot 5 \\
10 \cdot 5 \\
10 \cdot 2 \\
9.8\end{array}$ & $\begin{array}{l}2 \cdot 15 \\
2 \cdot 92 \\
3 \cdot 14 \\
3 \cdot 19\end{array}$ & $\begin{array}{r}13 \\
5 \\
15 \\
10\end{array}$ \\
\hline 3 months & $\begin{array}{r}\text { II } \\
\text { III } \\
\text { IV }\end{array}$ & $\begin{array}{l}\ldots \\
\cdots \\
\cdots \\
.\end{array}$ & $\begin{array}{l}10.8 \\
10.0 \\
12.2 \\
11.9\end{array}$ & $\begin{array}{l}3 \cdot 41 \\
3 \cdot 41 \\
4 \cdot 11 \\
3 \cdot 82\end{array}$ & $\begin{array}{l}14 \cdot 0 \\
12 \cdot 6 \\
14 \cdot 8 \\
14 \cdot 0\end{array}$ & $\begin{array}{l}4 \cdot 10 \\
4 \cdot 00 \\
5 \cdot 12 \\
4 \cdot 56\end{array}$ & $\begin{array}{l}9 \cdot 1 \\
8 \cdot 8 \\
9 \cdot 8 \\
9 \cdot 7\end{array}$ & $\begin{array}{l}2 \cdot 80 \\
2 \cdot 87 \\
3 \cdot 58 \\
3 \cdot 18\end{array}$ & $\begin{array}{r}11 \\
4 \\
12 \\
10\end{array}$ \\
\hline 4 months & $\begin{array}{r}\text { I } \\
\text { II } \\
\text { IV }\end{array}$ & $\begin{array}{l}\ldots \\
\cdots \\
\cdots\end{array}$ & $\begin{array}{l}10 \cdot 8 \\
11 \cdot 1 \\
11 \cdot 6 \\
12.5\end{array}$ & $\begin{array}{l}3 \cdot 63 \\
3 \cdot 80 \\
4 \cdot 32 \\
4 \cdot 37\end{array}$ & $\begin{array}{l}12 \cdot 2 \\
12 \cdot 6 \\
14 \cdot 0 \\
14.4\end{array}$ & $\begin{array}{l}4 \cdot 46 \\
4 \cdot 42 \\
5 \cdot 20 \\
5 \cdot 62\end{array}$ & $\begin{array}{r}9 \cdot 2 \\
10 \cdot 2 \\
8 \cdot 7 \\
10 \cdot 5\end{array}$ & $\begin{array}{l}2 \cdot 88 \\
3 \cdot 36 \\
3 \cdot 48 \\
3 \cdot 32\end{array}$ & $\begin{array}{r}10 \\
4 \\
14 \\
10\end{array}$ \\
\hline 5 months & $\begin{array}{r}\text { I } \\
\text { III } \\
\text { IV }\end{array}$ & $\begin{array}{l}\cdots \\
\ldots \\
\cdots\end{array}$ & $\begin{array}{l}10.2 \\
10.4 \\
11.2 \\
12.6\end{array}$ & $\begin{array}{l}3 \cdot 73 \\
3 \cdot 83 \\
4 \cdot 26 \\
4 \cdot 67\end{array}$ & $\begin{array}{l}11.9 \\
12.6 \\
13.0 \\
14.0\end{array}$ & $\begin{array}{l}4 \cdot 42 \\
4 \cdot 20 \\
5 \cdot 02 \\
6 \cdot 14\end{array}$ & $\begin{array}{r}7 \cdot 3 \\
8 \cdot 0 \\
8 \cdot 5 \\
10.6\end{array}$ & $\begin{array}{l}2 \cdot 58 \\
3 \cdot 46 \\
3 \cdot 66 \\
3 \cdot 50\end{array}$ & $\begin{array}{r}9 \\
4 \\
13 \\
10\end{array}$ \\
\hline 6 months & $\begin{array}{l}\text { I } \\
\text { II } \\
\text { III } \\
\text { IV }\end{array}$ & $\begin{array}{l}\ldots \\
\ldots \\
\cdots\end{array}$ & $\begin{array}{l}11.3 \\
11.9 \\
11.5 \\
12.9\end{array}$ & $\begin{array}{l}4 \cdot 19 \\
4 \cdot 03 \\
4 \cdot 73 \\
4 \cdot 56\end{array}$ & $\begin{array}{l}13 \cdot 3 \\
12 \cdot 6 \\
13 \cdot 3 \\
14 \cdot 7\end{array}$ & $\begin{array}{l}4 \cdot 96 \\
4 \cdot 26 \\
6 \cdot 40 \\
5 \cdot 27\end{array}$ & $\begin{array}{r}9 \cdot 0 \\
11 \cdot 2 \\
10 \cdot 0 \\
10.5\end{array}$ & $\begin{array}{l}3.45 \\
3.92 \\
3.96 \\
4.00\end{array}$ & $\begin{array}{r}10 \\
3 \\
11 \\
10\end{array}$ \\
\hline 9 months & $\begin{array}{r}\text { I } \\
\text { III } \\
\text { IV }\end{array}$ & $\begin{array}{l}\cdots \\
\cdots \\
\cdots\end{array}$ & $\begin{array}{l}12 \cdot 6 \\
12 \cdot 7 \\
12 \cdot 0 \\
12.0\end{array}$ & $\begin{array}{l}4 \cdot 37 \\
3 \cdot 94 \\
4 \cdot 66 \\
4 \cdot 76\end{array}$ & $\begin{array}{l}13 \cdot 3 \\
12 \cdot 9 \\
15 \cdot 7 \\
13 \cdot 6\end{array}$ & $\begin{array}{l}4 \cdot 70 \\
4 \cdot 88 \\
5 \cdot 32 \\
5 \cdot 06\end{array}$ & $\begin{array}{l}11.9 \\
12.6 \\
10.0 \\
10.5\end{array}$ & $\begin{array}{l}3 \cdot 98 \\
3 \cdot 01 \\
4 \cdot 16 \\
4 \cdot 42\end{array}$ & $\begin{array}{l}3 \\
2 \\
7 \\
6\end{array}$ \\
\hline 1 year & $\begin{array}{l}\text { II } \\
\text { III } \\
\text { IV }\end{array}$ & $\begin{array}{l}\ldots \\
\cdots \\
\cdots\end{array}$ & $\begin{array}{l}12 \cdot 6 \\
12 \cdot 9 \\
13 \cdot 0 \\
13 \cdot 3\end{array}$ & $\begin{array}{l}4 \cdot 09 \\
4 \cdot 25 \\
4 \cdot 44 \\
4 \cdot 44\end{array}$ & $\begin{array}{c}\overline{14 \cdot 7} \\
15 \cdot 4 \\
-\end{array}$ & $\begin{array}{c}-5 \cdot 00 \\
5 \cdot 07 \\
-\end{array}$ & $\begin{array}{l}\overline{11 \cdot 2} \\
11.9 \\
-\end{array}$ & $\begin{array}{c}-\overline{3 \cdot 50} \\
4 \cdot 10 \\
-\end{array}$ & $\begin{array}{l}1 \\
2 \\
3 \\
1\end{array}$ \\
\hline
\end{tabular}


TABLE 4

AVERAGE HAEMOGLOBIN CONTENT AND RED CELL COUNTS FROM BIRTH TO 1 YEAR IN INFANTS OF EIGHT TO NINE MONTHS' GESTATION

\begin{tabular}{|c|c|c|c|c|c|c|c|c|c|}
\hline \multirow[b]{2}{*}{ Age and } & \multirow[b]{2}{*}{ Group } & & \multicolumn{2}{|c|}{ Average Counts } & \multicolumn{2}{|c|}{ Maximum Counts } & \multicolumn{2}{|c|}{ Minimum Counts } & \multirow[b]{2}{*}{ No. of Cases } \\
\hline & & & Hb. (\%) & R.B.C. (m.) & Hb. (\%) & R.B.C. (m.) & Hb. (\%) & R.B.C. (m.) & \\
\hline Birth & $\underset{\text { III }}{\text { II }}$ & $\begin{array}{l}\cdots \\
\cdots \\
\cdots\end{array}$ & $\begin{array}{l}21 \cdot 8 \\
22 \cdot 3 \\
20 \cdot 2 \\
22 \cdot 0\end{array}$ & $\begin{array}{l}5 \cdot 82 \\
6 \cdot 10 \\
6 \cdot 10 \\
6 \cdot 12\end{array}$ & $\begin{array}{l}25 \cdot 2 \\
22 \cdot 4 \\
25 \cdot 2 \\
25 \cdot 2\end{array}$ & $\begin{array}{l}7 \cdot 38 \\
6 \cdot 98 \\
7 \cdot 20 \\
7 \cdot 12\end{array}$ & $\begin{array}{l}15 \cdot 7 \\
15 \cdot 7 \\
18 \cdot 2 \\
17 \cdot 6\end{array}$ & $\begin{array}{l}4 \cdot 58 \\
4 \cdot 42 \\
5 \cdot 16 \\
5 \cdot 68\end{array}$ & $\begin{array}{r}30 \\
12 \\
12 \\
8\end{array}$ \\
\hline 1 month & $\begin{array}{c}\text { II } \\
\text { III } \\
\text { IV }\end{array}$ & $\begin{array}{l}\cdots \\
\cdots \\
\cdots\end{array}$ & $\begin{array}{l}13 \cdot 9 \\
14 \cdot 7 \\
13 \cdot 4 \\
15 \cdot 0\end{array}$ & $\begin{array}{l}4 \cdot 14 \\
4 \cdot 39 \\
4 \cdot 20 \\
4 \cdot 04\end{array}$ & $\begin{array}{l}17 \cdot 6 \\
18 \cdot 9 \\
16 \cdot 0 \\
17 \cdot 1\end{array}$ & $\begin{array}{l}5 \cdot 50 \\
5 \cdot 74 \\
5 \cdot 76 \\
4 \cdot 54\end{array}$ & $\begin{array}{l}10 \cdot 6 \\
10 \cdot 9 \\
11 \cdot 1 \\
13 \cdot 2\end{array}$ & $\begin{array}{l}2 \cdot 92 \\
2 \cdot 59 \\
2 \cdot 84 \\
3 \cdot 16\end{array}$ & $\begin{array}{r}17 \\
12 \\
12 \\
8\end{array}$ \\
\hline 2 months & $\underset{\text { III }}{\text { II }}$ & $\begin{array}{l}\ldots \\
\cdots \\
\cdots\end{array}$ & $\begin{array}{l}10.9 \\
11.6 \\
12.5 \\
12.6\end{array}$ & $\begin{array}{l}3 \cdot 54 \\
3 \cdot 75 \\
4 \cdot 14 \\
4 \cdot 41\end{array}$ & $\begin{array}{l}12 \cdot 6 \\
16 \cdot 1 \\
14 \cdot 1 \\
16 \cdot 0\end{array}$ & $\begin{array}{l}4 \cdot 36 \\
4 \cdot 50 \\
4 \cdot 78 \\
5 \cdot 90\end{array}$ & $\begin{array}{r}9.5 \\
9.2 \\
10.6 \\
11 \cdot 2\end{array}$ & $\begin{array}{l}2 \cdot 64 \\
3 \cdot 24 \\
3 \cdot 40 \\
3 \cdot 58\end{array}$ & $\begin{array}{r}14 \\
11 \\
12 \\
8\end{array}$ \\
\hline 3 months & III & $\begin{array}{l}\ldots \\
\cdots \\
\cdots\end{array}$ & $\begin{array}{l}10 \cdot 8 \\
10.8 \\
11.8 \\
11.9\end{array}$ & $\begin{array}{l}3 \cdot 75 \\
3 \cdot 60 \\
4 \cdot 44 \\
4 \cdot 34\end{array}$ & $\begin{array}{l}12 \cdot 6 \\
14 \cdot 8 \\
13 \cdot 3 \\
12 \cdot 5\end{array}$ & $\begin{array}{l}4 \cdot 48 \\
4 \cdot 34 \\
5 \cdot 56 \\
5 \cdot 00\end{array}$ & $\begin{array}{r}9 \cdot 2 \\
8 \cdot 8 \\
9 \cdot 8 \\
11 \cdot 2\end{array}$ & $\begin{array}{l}2 \cdot 84 \\
2 \cdot 87 \\
3 \cdot 58 \\
3 \cdot 76\end{array}$ & $\begin{array}{r}13 \\
11 \\
11 \\
6\end{array}$ \\
\hline 4 months & III & $\begin{array}{l}\cdots \\
\cdots \\
\cdots\end{array}$ & $\begin{array}{l}11 \cdot 1 \\
11 \cdot 5 \\
11 \cdot 8 \\
12.6\end{array}$ & $\begin{array}{l}3 \cdot 72 \\
4 \cdot 15 \\
4 \cdot 30 \\
4 \cdot 19\end{array}$ & $\begin{array}{l}12.6 \\
15.4 \\
14.0 \\
14.6\end{array}$ & $\begin{array}{l}4 \cdot 70 \\
5 \cdot 02 \\
5 \cdot 48 \\
4 \cdot 76\end{array}$ & $\begin{array}{r}8 \cdot 4 \\
9 \cdot 2 \\
8 \cdot 7 \\
11 \cdot 9\end{array}$ & $\begin{array}{l}2 \cdot 59 \\
3 \cdot 44 \\
3 \cdot 56 \\
3 \cdot 66\end{array}$ & $\begin{array}{r}13 \\
11 \\
12 \\
6\end{array}$ \\
\hline 5 months & $\underset{\text { III }}{\text { I }}$ & $\begin{array}{l}\cdots \\
\cdots \\
\cdots\end{array}$ & $\begin{array}{l}11 \cdot 1 \\
11 \cdot 5 \\
11 \cdot 8 \\
11.9\end{array}$ & $\begin{array}{l}3 \cdot 99 \\
4 \cdot 38 \\
4 \cdot 39 \\
4 \cdot 12\end{array}$ & $\begin{array}{l}13 \cdot 3 \\
15 \cdot 0 \\
13 \cdot 3 \\
12 \cdot 3\end{array}$ & $\begin{array}{l}4 \cdot 98 \\
4 \cdot 92 \\
5 \cdot 50 \\
4 \cdot 74\end{array}$ & $\begin{array}{r}7 \cdot 3 \\
8 \cdot 0 \\
8 \cdot 8 \\
11 \cdot 5\end{array}$ & $\begin{array}{l}2 \cdot 58 \\
3 \cdot 46 \\
3 \cdot 95 \\
3 \cdot 58\end{array}$ & $\begin{array}{r}12 \\
11 \\
11 \\
5\end{array}$ \\
\hline 6 months & $\underset{\text { III }}{\text { II }}$ & $\begin{array}{l}\cdots \\
\cdots \\
\cdots\end{array}$ & $\begin{array}{l}11.6 \\
11.6 \\
11.8 \\
12.0\end{array}$ & $\begin{array}{l}4 \cdot 24 \\
4 \cdot 29 \\
4 \cdot 54 \\
4 \cdot 62\end{array}$ & $\begin{array}{l}13 \cdot 3 \\
14.0 \\
13.9 \\
12.9\end{array}$ & $\begin{array}{l}4 \cdot 96 \\
4 \cdot 79 \\
6 \cdot 40 \\
5 \cdot 10\end{array}$ & $\begin{array}{r}8 \cdot 0 \\
9.2 \\
9.8 \\
10.6\end{array}$ & $\begin{array}{l}3 \cdot 48 \\
3 \cdot 66 \\
3 \cdot 96 \\
4 \cdot 10\end{array}$ & $\begin{array}{r}10 \\
8 \\
10 \\
4\end{array}$ \\
\hline 9 months & $\begin{array}{r}\text { I } \\
\text { III } \\
\text { IV }\end{array}$ & $\begin{array}{l}\cdots \\
\cdots \\
\cdots\end{array}$ & $\begin{array}{l}12.9 \\
12.5 \\
12.9 \\
12.0\end{array}$ & $\begin{array}{l}4 \cdot 63 \\
4 \cdot 00 \\
4 \cdot 58 \\
4 \cdot 62\end{array}$ & $\begin{array}{l}14 \cdot 0 \\
13 \cdot 6 \\
14 \cdot 0 \\
12 \cdot 3\end{array}$ & $\begin{array}{l}5 \cdot 62 \\
4 \cdot 72 \\
5 \cdot 56 \\
5 \cdot 26\end{array}$ & $\begin{array}{l}10.9 \\
10.5 \\
11.2 \\
11.9\end{array}$ & $\begin{array}{l}4 \cdot 03 \\
3 \cdot 01 \\
3 \cdot 68 \\
3 \cdot 98\end{array}$ & $\begin{array}{l}6 \\
5 \\
7 \\
2\end{array}$ \\
\hline 1 year & $\begin{array}{r}\text { I } \\
\text { II } \\
\text { III } \\
\text { IV }\end{array}$ & $\begin{array}{l}\ldots \\
\cdots \\
\cdots\end{array}$ & $\begin{array}{l}12 \cdot 2 \\
12 \cdot 3 \\
11 \cdot 8 \\
12.9\end{array}$ & $\begin{array}{l}4 \cdot 25 \\
3 \cdot 82 \\
4 \cdot 45 \\
4 \cdot 33\end{array}$ & $\begin{array}{c}14 \cdot 0 \\
13 \cdot 4 \\
12.6 \\
-\end{array}$ & $\begin{array}{c}5 \cdot 00 \\
4 \cdot 15 \\
4 \cdot 77 \\
-\end{array}$ & $\begin{array}{c}11 \cdot 2 \\
11 \cdot 2 \\
11 \cdot 2 \\
-\end{array}$ & $\begin{array}{c}3 \cdot 40 \\
3 \cdot 50 \\
4 \cdot 16 \\
-\end{array}$ & $\begin{array}{l}3 \\
2 \\
5 \\
1\end{array}$ \\
\hline
\end{tabular}

it is more severe in the artificially fed. The incidence of breast feeding in our series is shown in Table 10. Any infant breast fed for five months or longer without regular complements was considered as fully breast fed. Partial breast feeding included cases fed for any period over one month and infants who received breast milk together with more than occasional complements. Any infant on the breast for less than one month was classified as 'never breast fed'. Consideration of Table 10 makes it clear that the higher blood levels obtained in the treated cases was in no way due to breast feeding as the incidence of breast feeding was considerably higher in the control group than in any other. The cases for each group were selected at birth before feeding had begun at all, and we cannot explain this difference in feeding methods which appears to be entirely fortuitous.

In view of the conflicting evidence about the effect of cobalt on appetite and weight gain in both animals and man, the weights of all infants were recorded at each attendance. The average weight gain in ounces over birth weight at 2, 4 and 6 months of age are shown in Table 10, together with the average birth weight of each group. The birth weights in the four groups were comparable and the differences in weight gain are not significant. At 2 months all infants had finished cobalt treatment and this therefore seemed a suitable time to start comparisons.

There was no evidence of toxicity in any case under treatment; appetite and vigour were good and the preparation was readily taken in water or milk. There is nothing to suggest that cobalt in any way impairs the general progress or rate of weight gain in premature infants in the dosage employed.

In the cases which developed anaemia symptoms were confined to pallor except in the baby already 
TABLE 5

AVERAGE HAEMOGLOBIN CONTENT AND RED CELL COUNTS FROM BIRTH TO 1 YEAR IN INFANTS OF SIX TO EIGHT MONTHS' GESTATION

\begin{tabular}{|c|c|c|c|c|c|c|c|c|c|}
\hline \multirow[b]{2}{*}{ Age and } & \multirow[b]{2}{*}{ Group } & \multicolumn{3}{|c|}{ Average Counts } & \multicolumn{2}{|c|}{ Maximum Counts } & \multicolumn{2}{|c|}{ Minimum Counts } & \multirow[b]{2}{*}{ No. of Cases } \\
\hline & & & Hb. (\%) & R.B.C. (m.) & Hb. (\%) & R.B.C. (m.) & Hb. (\%) & R.B.C. (m.) & \\
\hline Birth & $\begin{array}{c}\text { I } \\
\text { III } \\
\text { IV }\end{array}$ & $\begin{array}{l}. \\
\therefore \\
. \\
.\end{array}$ & $\begin{array}{l}21.4 \\
20.6 \\
20.6 \\
21.4\end{array}$ & $\begin{array}{l}5 \cdot 71 \\
5 \cdot 83 \\
5 \cdot 35 \\
5 \cdot 21\end{array}$ & $\begin{array}{l}25 \cdot 2 \\
24 \cdot 5 \\
25 \cdot 2 \\
24 \cdot 5\end{array}$ & $\begin{array}{l}7 \cdot 20 \\
6 \cdot 60 \\
6 \cdot 80 \\
6 \cdot 50\end{array}$ & $\begin{array}{l}15 \cdot 3 \\
15 \cdot 7 \\
14 \cdot 3 \\
16 \cdot 8\end{array}$ & $\begin{array}{l}4 \cdot 10 \\
5 \cdot 12 \\
3 \cdot 92 \\
4 \cdot 60\end{array}$ & $\begin{array}{l}23 \\
10 \\
17 \\
14\end{array}$ \\
\hline 1 month & $\underset{\text { IV }}{\text { II }}$ & $\begin{array}{l}. \\
\cdots \\
\cdots\end{array}$ & $\begin{array}{l}14 \cdot 7 \\
15.0 \\
14 \cdot 3 \\
14.8\end{array}$ & $\begin{array}{l}3.85 \\
4.46 \\
3.89 \\
4.00\end{array}$ & $\begin{array}{l}19 \cdot 2 \\
18.2 \\
19 \cdot 6 \\
18.7\end{array}$ & $\begin{array}{l}4.96 \\
5 \cdot 36 \\
5 \cdot 36 \\
5 \cdot 42\end{array}$ & $\begin{array}{r}10.6 \\
11.9 \\
8.8 \\
11 \cdot 2\end{array}$ & $\begin{array}{l}2.90 \\
3.98 \\
2.62 \\
3.35\end{array}$ & $\begin{array}{r}18 \\
8 \\
17 \\
14\end{array}$ \\
\hline 2 months & $\begin{array}{l}\text { I } \\
\text { III } \\
\text { IV }\end{array}$ & $\begin{array}{l}. \\
\cdots \\
\cdots\end{array}$ & $\begin{array}{l}10 \cdot 6 \\
12 \cdot 3 \\
12 \cdot 5 \\
12 \cdot 2\end{array}$ & $\begin{array}{l}3.06 \\
3.85 \\
4 \cdot 13 \\
3.83\end{array}$ & $\begin{array}{l}13 \cdot 2 \\
13 \cdot 3 \\
17 \cdot 5 \\
15 \cdot 4\end{array}$ & $\begin{array}{l}3 \cdot 98 \\
4 \cdot 82 \\
5 \cdot 32 \\
4 \cdot 92\end{array}$ & $\begin{array}{r}8 \cdot 5 \\
10 \cdot 5 \\
9 \cdot 8 \\
9 \cdot 8\end{array}$ & $\begin{array}{l}2 \cdot 15 \\
2 \cdot 92 \\
3 \cdot 14 \\
3 \cdot 19\end{array}$ & $\begin{array}{r}14 \\
7 \\
17 \\
14\end{array}$ \\
\hline 3 months & $\begin{array}{l}\text { II } \\
\text { III } \\
\text { IV }\end{array}$ & $\begin{array}{l}. \\
\cdots \\
\cdots\end{array}$ & $\begin{array}{l}10.8 \\
11.2 \\
12.0 \\
12.2\end{array}$ & $\begin{array}{l}3.40 \\
3.81 \\
4 \cdot 20 \\
4 \cdot 01\end{array}$ & $\begin{array}{l}14 \cdot 0 \\
12 \cdot 6 \\
14 \cdot 8 \\
14 \cdot 1\end{array}$ & $\begin{array}{l}4 \cdot 10 \\
4 \cdot 00 \\
5 \cdot 14 \\
5 \cdot 70\end{array}$ & $\begin{array}{l}9 \cdot 1 \\
9 \cdot 8 \\
9 \cdot 0 \\
9 \cdot 7\end{array}$ & $\begin{array}{l}2.68 \\
3.62 \\
3.60 \\
3 \cdot 18\end{array}$ & $\begin{array}{r}11 \\
4 \\
15 \\
14\end{array}$ \\
\hline 4 months & III & $\begin{array}{l}\ldots \\
\cdots \\
\cdots\end{array}$ & $\begin{array}{l}10.6 \\
11.2 \\
11.5 \\
12.6\end{array}$ & $\begin{array}{l}3 \cdot 60 \\
4 \cdot 09 \\
4 \cdot 30 \\
4 \cdot 41\end{array}$ & $\begin{array}{l}12 \cdot 2 \\
12 \cdot 6 \\
13 \cdot 7 \\
14 \cdot 4\end{array}$ & $\begin{array}{l}4.46 \\
4.42 \\
5.08 \\
5.62\end{array}$ & $\begin{array}{r}9 \cdot 2 \\
10 \cdot 2 \\
7 \cdot 4 \\
10 \cdot 5\end{array}$ & $\begin{array}{l}2 \cdot 88 \\
3 \cdot 36 \\
3 \cdot 48 \\
3 \cdot 32\end{array}$ & $\begin{array}{r}10 \\
4 \\
16 \\
14\end{array}$ \\
\hline 5 months & $\underset{\text { III }}{\text { II }}$ & $\begin{array}{l}. \\
\cdots \\
\cdots \\
.\end{array}$ & $\begin{array}{l}10.4 \\
11.8 \\
11.5 \\
12.7\end{array}$ & $\begin{array}{l}3 \cdot 71 \\
4 \cdot 06 \\
4 \cdot 39 \\
4 \cdot 52\end{array}$ & $\begin{array}{l}11.9 \\
12.9 \\
13.9 \\
14.0\end{array}$ & $\begin{array}{l}4 \cdot 44 \\
4 \cdot 34 \\
5 \cdot 24 \\
6 \cdot 14\end{array}$ & $\begin{array}{r}9 \cdot 2 \\
9 \cdot 8 \\
9 \cdot 8 \\
10 \cdot 6\end{array}$ & $\begin{array}{l}3 \cdot 10 \\
3 \cdot 80 \\
3 \cdot 66 \\
3 \cdot 50\end{array}$ & $\begin{array}{r}9 \\
4 \\
13 \\
14\end{array}$ \\
\hline 6 months & $\begin{array}{l}\text { I } \\
\text { II } \\
\text { III } \\
\text { IV }\end{array}$ & $\begin{array}{l}. \\
\cdots \\
.\end{array}$ & $\begin{array}{l}10.9 \\
12.2 \\
11.6 \\
13.0\end{array}$ & $\begin{array}{l}4 \cdot 13 \\
4 \cdot 22 \\
4 \cdot 60 \\
4 \cdot 57\end{array}$ & $\begin{array}{l}13.3 \\
12.6 \\
13.9 \\
14.7\end{array}$ & $\begin{array}{l}4 \cdot 84 \\
4 \cdot 74 \\
5 \cdot 36 \\
5 \cdot 27\end{array}$ & $\begin{array}{r}9 \cdot 0 \\
11.9 \\
10 \cdot 0 \\
10 \cdot 5\end{array}$ & $\begin{array}{l}3.45 \\
3.92 \\
3.96 \\
3.89\end{array}$ & $\begin{array}{r}11 \\
4 \\
13 \\
14\end{array}$ \\
\hline 9 months & $\begin{array}{l}\text { I } \\
\text { II } \\
\text { III } \\
\text { IV }\end{array}$ & $\begin{array}{l}. \\
\cdots \\
\cdots \\
.\end{array}$ & $\begin{array}{l}11 \cdot 2 \\
11 \cdot 9 \\
12 \cdot 3 \\
12 \cdot 3\end{array}$ & $\begin{array}{l}4 \cdot 05 \\
4.83 \\
4.60 \\
4 \cdot 66\end{array}$ & $\begin{array}{l}12.6 \\
12.9 \\
15.7 \\
13.6\end{array}$ & $\begin{array}{l}4 \cdot 70 \\
4 \cdot 88 \\
5 \cdot 32 \\
5 \cdot 06\end{array}$ & $\begin{array}{r}8 \cdot 4 \\
11 \cdot 5 \\
10 \cdot 0 \\
10 \cdot 5\end{array}$ & $\begin{array}{l}3 \cdot 61 \\
4 \cdot 74 \\
3 \cdot 91 \\
4 \cdot 06\end{array}$ & $\begin{array}{l}4 \\
3 \\
8 \\
8\end{array}$ \\
\hline 1 year & $\begin{array}{l}\text { I } \\
\text { II } \\
\text { III } \\
\text { IV }\end{array}$ & $\begin{array}{l}\cdots \\
\cdots \\
\cdots\end{array}$ & $\begin{array}{l}12 \cdot 2 \\
13 \cdot 2 \\
13 \cdot 3 \\
12 \cdot 7\end{array}$ & $\begin{array}{l}3 \cdot 96 \\
4 \cdot 34 \\
4 \cdot 53 \\
4 \cdot 07\end{array}$ & $\begin{array}{l}12 \cdot 6 \\
14 \cdot 7 \\
15 \cdot 4 \\
13 \cdot 3\end{array}$ & $\begin{array}{l}4.09 \\
5.00 \\
5.07 \\
4.44\end{array}$ & $\begin{array}{l}11.9 \\
11.5 \\
11.9 \\
11.6\end{array}$ & $\begin{array}{l}3 \cdot 84 \\
3 \cdot 97 \\
4 \cdot 10 \\
3 \cdot 41\end{array}$ & $\begin{array}{l}2 \\
3 \\
3 \\
3\end{array}$ \\
\hline
\end{tabular}

mentioned (P.S.) who was treated with cobalt at 5 months. However, after treatment with iron or cobalt, the mothers of these anaemic infants frequently stated spontaneously that the children were much improved, with increased appetite and vigour. It seems possible, therefore, that even if anaemia in premature infants does not usually produce marked symptoms, there is a subclinical debility which becomes more evident in retrospect.

\section{Discussion}

Our average values for control cases do not show a very severe anaemia, reaching lowest values of $10.8 \mathrm{~g}$. haemoglobin, and $3.75 \mathrm{~m}$. red cells at 3 months of age for infants of eight to nine months' gestation, and $10.6 \mathrm{~g}$. haemoglobin and $3.06 \mathrm{~m}$. red cells at 2 months for those of six to eight months' gestation. These figures are, however, well below those given by Herz (1928) as indicative of anaemia. The subsequent satisfactory increases and the relatively few cases requiring iron therapy are, we feel, partly due to the early introduction of a mixed diet with a liberal supply of iron-containing foods, and partly to the continuous supervision by one team employing the same feeding methods. This meant that mothers could follow a regular plan and had a feeling of security where diet was concerned, a factor missing if feeding advice is obtained from several sources.

It is a significant fact that none of the Group IV cases receiving iron as well as cobalt required additional iron therapy and that the haemoglobin levels of this group remained consistently and significantly higher than those in any other group after the age of 4 months. No attempt is made in this paper to determine the exact mechanism of cobalt in stimulating erythropoiesis but it would appear that its action is in part due to a favourable influence on the utilization of available iron for blood synthesis. The Group III infants who developed 
TABLE 6

STATISTICAL ANALYSIS OF AVERAGE HAEMOGLOBIN CONTENT OF BLOOD TO 6 MONTHS* OF AGE

\begin{tabular}{|c|c|c|c|c|c|c|c|c|c|}
\hline \multirow[b]{2}{*}{. Group } & \multicolumn{2}{|c|}{ No. of Cases } & \multicolumn{7}{|c|}{ Age in Months } \\
\hline & 1 month & 6 months & Birth & 1 & 2 & 3 & 4 & 5 & 6 \\
\hline$\cdots$ & 35 & 21 & $21 \cdot 75$ & $14 \cdot 40$ & $10 \cdot 78$ & $10 \cdot 78$ & $10 \cdot 93$ & $10 \cdot 93$ & $11 \cdot 35$ \\
\hline II & 20 & 12 & $21 \cdot 50$ & $15 \cdot 10$ & $11 \cdot 81$ & $10 \cdot 97$ & $11 \cdot 61$ & $11 \cdot 66$ & $11 \cdot 83$ \\
\hline III & 29 & 23 & $20 \cdot 80$ & $14 \cdot 08$ & $12 \cdot 64$ & $12 \cdot 02$ & $11 \cdot 72$ & $11 \cdot 64$ & $11 \cdot 78$ \\
\hline IV $\quad \ldots$ & 22 & 18 & $21 \cdot 67$ & $14 \cdot 99$ & $12 \cdot 40$ & $12 \cdot 14$ & $12 \cdot 69$ & $12 \cdot 55$ & $12 \cdot 87$ \\
\hline $\begin{array}{l}\text { I and II } \\
\text { combined }\end{array}$ & 55 & 33 & $21 \cdot 67$ & $14 \cdot 66$ & $11 \cdot 18$ & $10 \cdot 85$ & $11 \cdot 20$ & $11 \cdot 24$ & $11 \cdot 52$ \\
\hline $\begin{array}{l}\text { III and IV } \\
\text { combined }\end{array}$ & 51 & 41 & $21 \cdot 18$ & $14 \cdot 47$ & $12 \cdot 54$ & $12 \cdot 07$ & $12 \cdot 13$ & $\stackrel{+}{12} \cdot 03$ & $12 \cdot 26$ \\
\hline
\end{tabular}

* Cases grouped irrespective of birth weight or gestation period.

$\dagger$ The difference between this pair of means is significant at the $5 \%$ level.

TABLE 7

STATISTICAL ANALYSIS OF AVERAGE RED CELL COUNTS TO 6 MONTHS* OF AGE

\begin{tabular}{|c|c|c|c|c|c|c|c|c|c|}
\hline \multirow[b]{2}{*}{ Group } & \multicolumn{2}{|c|}{ No. of Cases } & \multicolumn{7}{|c|}{ Age in Months } \\
\hline & 1 month & 6 months & Birth & 1 & 2 & 3 & 4 & 5 & 6 \\
\hline$\cdots$ & 35 & 21 & $5 \cdot 76$ & $3 \cdot 96$ & $3 \cdot 34$ & $3 \cdot 57$ & $3 \cdot 70$ & $3 \cdot 91$ & $4 \cdot 19$ \\
\hline II & 20 & 12 & $5 \cdot 98$ & $\begin{array}{c}t \\
4 \cdot 42\end{array}$ & $3 \cdot 79$ & $3 \cdot 66$ & $4 \cdot \stackrel{t}{17}$ & $4 \cdot \stackrel{\dagger}{\dagger} 0$ & $4 \cdot 27$ \\
\hline III & 29 & 23 & $5 \cdot 67$ & $4 \cdot 01$ & $4 \cdot 14$ & $4 \cdot 32$ & $4 \cdot 30$ & $4 \cdot 39$ & $4 \cdot 59$ \\
\hline IV & 22 & 18 & $5 \cdot 78$ & $4 \cdot 08$ & $4 \cdot 04$ & $4 \cdot 11$ & $4 \cdot 36$ & $4 \cdot 46$ & $4 \cdot 58$ \\
\hline $\begin{array}{l}\text { I and II } \\
\text { combined }\end{array}$ & 55 & 33 & $5 \cdot 82$ & $4 \cdot 13$ & $3 \cdot 52$ & $3 \cdot 60$ & $3 \cdot 89$ & $4 \cdot 07$ & $4 \cdot 22$ \\
\hline $\begin{array}{l}\text { III and IV } \\
\text { combined }\end{array}$ & 51 & 41 & $5 \cdot 72$ & $4 \cdot 04$ & $4 \cdot \stackrel{+}{10}$ & $4 \cdot \stackrel{\dagger}{23}$ & $\begin{array}{c}+ \\
4 \cdot 33\end{array}$ & $4 \cdot 42$ & $84 \cdot 9$ \\
\hline
\end{tabular}

* Cases grouped irrespective of birth weight or gestation period.

+ The difference between this pair of means is significant at the $5 \%$ level.

an iron deficiency anaemia were presumably lacking in endogenous iron or had a poor absorption. Two of the three cases requiring iron in this group were twins and this may account for their low iron content. We agree with Waltner (1930) and Virdis (1952) that iron should be given together with cobalt to obtain the most satisfactory results. Although no group of cases received cobalt after the end of the second month, it appears from our results that this substance may be stored in the body and utilized when needed. All three infants who received cobalt from 4 to 8 weeks but subsequently developed an iron deficiency anaemia had adequate red cell counts, and this suggests that direct stimulation of the erythroid tissue of the marrow is also a factor in the haemopoietic action of cobalt. The effect of cobalt on the marrow requires further elucidation and this aspect of its action is now being investigated.
Animal studies with radioactive cobalt have shown that young animals absorb more than adult animals and that they have higher blood levels after oral administration (Comar and Davis, 1947). The liver appears to be the principal storage organ, though in animals relatively little is retained, about $5 \%$ of an intravenous dose after 10 days in cattle (Comar, Davis and Taylor, 1946). It is not known whether these results are applicable to man, but in any case it is probable that only extremely small amounts are necessary to produce a haemopoietic effect. The detectable dose of cobalt which will produce polycythaemia in rats is $0.15 \mathrm{mg}$. daily, and $2 \mathrm{mg}$. per $\mathrm{kg}$. body weight is capable of causing polycythaemia in dogs (Frost et al., 1941). Our dosage in this series has been arbitrary and based on the existing reports of the therapeutic use of cobalt in man together with the doses used to produce polycythaemia in animals. It is possible that more prolonged treatment would 
TABLE 8

DATA FOR CASES ON THERAPEUTIC COBALT

\begin{tabular}{|c|c|c|c|c|c|c|c|c|c|c|}
\hline \multirow{2}{*}{\multicolumn{4}{|c|}{$\begin{array}{l}\text { Name and } \\
\text { Birth Weight }\end{array}$}} & \multirow{3}{*}{$\begin{array}{c}\begin{array}{c}\text { Prematurity } \\
\text { in } \\
\text { Weeks }\end{array} \\
5\end{array}$} & \multirow{3}{*}{$\begin{array}{c}\begin{array}{c}\text { Age } \\
\text { Cobalt } \\
\text { Started }\end{array} \\
2 \text { months }\end{array}$} & \multirow{3}{*}{$\frac{\begin{array}{c}\text { Duration } \\
\text { of } \\
\text { Therapy }\end{array}}{1 \text { month }}$} & \multicolumn{2}{|c|}{ Hb. (\%) } & \multicolumn{2}{|c|}{ R.B.C. (m.) } \\
\hline & & & & & & & \multirow{2}{*}{$\frac{\text { Before }}{65}$} & \multirow{2}{*}{$\begin{array}{c}\text { After } \\
86\end{array}$} & \multirow{2}{*}{$\frac{\text { Before }}{2 \cdot 15}$} & \multirow{2}{*}{$\frac{\text { After }}{4 \cdot 32}$} \\
\hline R.W. & 3.10 & Twin & $\ldots$ & & & & & & & \\
\hline J.B. & 3.15 . & Twin* & $\ldots$ & 3 & 5 months & 2 months & 52 & 70 & $2 \cdot 58$ & $4 \cdot 70$ \\
\hline A.Q. & 4 lb. & Twin & $\ldots$ & 4 & 2 months & 1 month & 69 & 79 & $2 \cdot 48$ & $3 \cdot 58$ \\
\hline P.S. & 4.9 & .. & . & 2 & 5 months & 1 month & 66 & 60 & $3 \cdot 08$ & $4 \cdot 16$ \\
\hline
\end{tabular}

All cases controls. Dosage $20 \mathrm{mg}$. daily.

* Plus iron for second month of treatment.

TABLE 9

DATA FOR CASES REQUIRING IRON

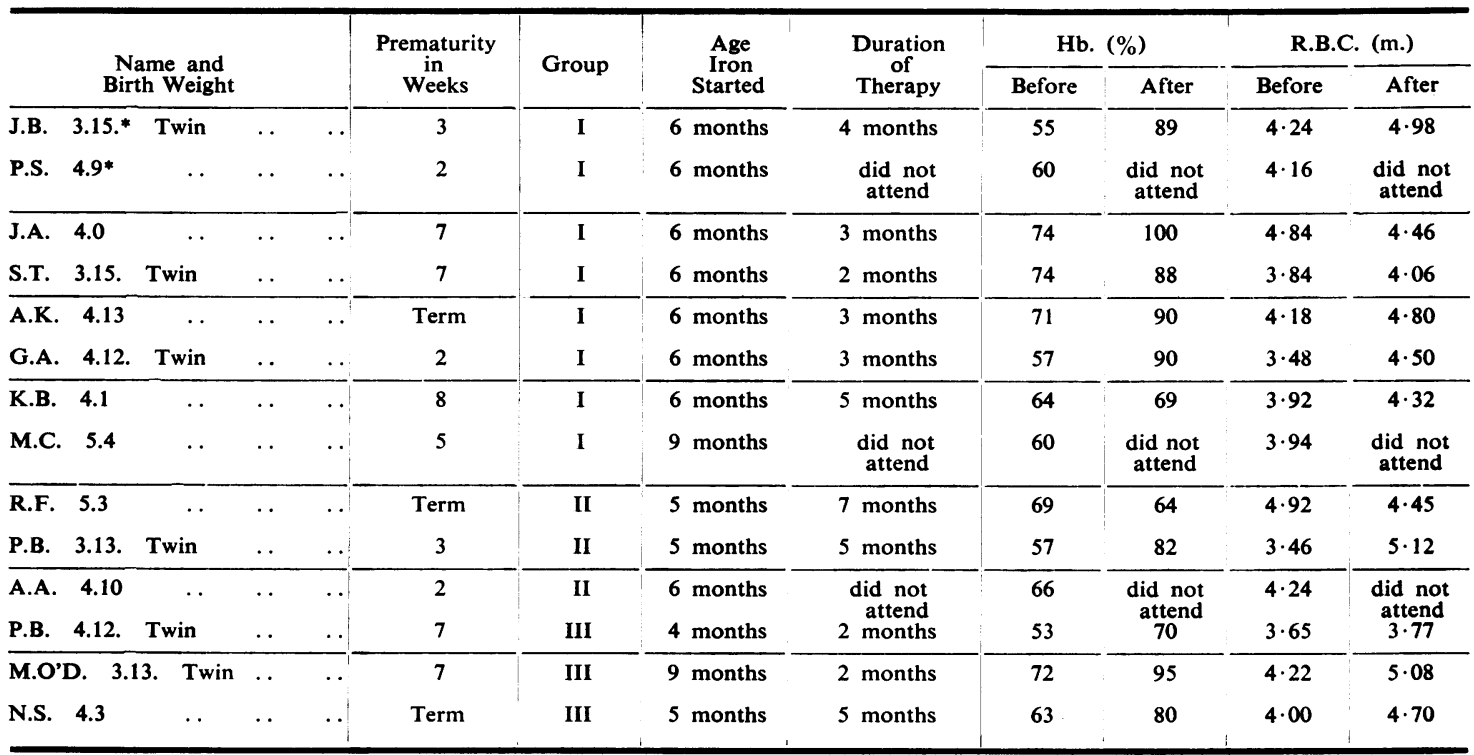

* After one month of cobalt.

TABLE 10

INCIDENCE OF BREAST FEEDING AND AVERAGE GAIN OVER BIRTH WEIGHT AT 2, 4 AND 6 MONTHS

\begin{tabular}{|c|c|c|c|c|c|c|c|c|c|}
\hline \multirow{2}{*}{ Group } & & \multirow{2}{*}{$\begin{array}{c}\text { Number of } \\
\text { Infants }\end{array}$} & \multicolumn{3}{|c|}{ Breast Fed (\%) } & \multirow{2}{*}{$\begin{array}{c}\text { Average } \\
\text { B.W. }\end{array}$} & \multicolumn{3}{|c|}{ Average Gain over B.W. (oz.) } \\
\hline & & & Fully & Partly & Never & & 2 Months & 4 Months & 6 Months \\
\hline $\mathbf{I}$ & $\cdots$ & 21 & $53 \cdot 8$ & $38 \cdot 6$ & $7 \cdot 6$ & $4 \cdot 11$ & $57 \cdot 0$ & $118 \cdot 4$ & $169 \cdot 2$ \\
\hline II & $\cdots$ & 15 & $36 \cdot 8$ & $36 \cdot 8$ & $26 \cdot 4$ & $4 \cdot 7$ & $61 \cdot 9$ & $117 \cdot 5$ & $173 \cdot 9$ \\
\hline III & $\cdots$ & 28 & $31 \cdot 2$ & $46 \cdot 9$ & $21 \cdot 9$ & $4 \cdot 7$ & $57 \cdot 7$ & $114 \cdot 7$ & $160 \cdot 8$ \\
\hline IV & $\cdots$ & 21 & $25 \cdot 9$ & $48 \cdot 2$ & $25 \cdot 9$ & $4 \cdot 10$ & $47 \cdot 0$ & $104 \cdot 1$ & $156 \cdot 3$ \\
\hline$I$ and II & $\cdots$ & 36 & - & - & - & $4 \cdot 9$ & $59 \cdot 1$ & $118 \cdot 0$ & $171 \cdot 1$ \\
\hline III and IV & $\ldots$ & 49 & - & - & - & $4 \cdot 8 \frac{1}{2}$ & $53 \cdot 1$ & $110 \cdot 1$ & $158 \cdot 9$ \\
\hline
\end{tabular}


be of greater benefit and we feel that more work is needed before the role of cobalt in the prevention of the anaemia of prematurity can be fully defined.

\section{Summary and Conclusions}

The experimental literature of cobalt as a haemopoietic agent is briefly summarized, and a more detailed review is given of its use in the treatment of anaemia in man.

One hundred and twenty-six premature infants were divided into four groups. Eighty-three were followed up six months or longer. Group I acted as controls. Group II received cobalt sulphate, $10 \mathrm{mg}$. daily, from one to 12 days. Group III received cobalt sulphate, $20 \mathrm{mg}$. daily, from four to eight weeks. Group IV received cobalt sulphate, $20 \mathrm{mg}$., and ferrous sulphate, gr. $4 \frac{1}{2}$ daily, from four to eight weeks.

Cobalt appears to be of value in the prevention of the early anaemia of premature infants, and if iron is administered simultaneously the risk of an iron deficiency anaemia developing from the fourth month onwards is considerably reduced. Cobalt has no toxic effects and no unfavourable influence on the weight gain in the dosage employed. The mode of action is uncertain but two possibilities seem likely: (1) a direct action on the erythropoietic tissue in the marrow; (2) a possible catalytic action enabling available iron to be more readily utilized for haemoblobin synthesis.

This work was carried out under a grant from the Endowment Fund of the Royal Free Hospital.

Our thanks are due to the resident medical officers and nursing staff of the maternity units for their cooperation, and also to the Medical Committee of the Elizabeth
Garrett Anderson Hospital for providing the laboratory accommodation in which the haematological part of this investigation was carried out. We are particularly grateful to Dr. Ian Sutherland, of the M.R.C. Statistical Research Unit, for his statistical analysis of our results and we are indebted to him for Tables 6,7 and 10.

\section{REFERENCES}

Abt, A. F. (1935), Amer. J. Dis. Child., 49, 1204.

and Nagel, B. R. (1932). J. Amer. med. Ass., 98, 2270.

Baxter, C. R. (1939). Brit. med. J., 1, 534.

Berk, L., Burchenal, J. H. and Castle, W. B. (1949). New Engl. J. Med., 240, 754.

Cartwright, G. E. (1947). Blood, 2, 256.

Caussade, L., Franck, C. and Petitdant-Monniot, L. (1947). Arch. franc. Pediat., 4, 293.

Comar, C. L. and Davis, G. K. (1947). J. biol. Chem., 170, 379.

, and Taylor, R. F. (1946). Arch. Biochem., 9, 149.

Cronin, E. (1939). Brit. med. J., 1, 643.

Davis, J. E., McCullough, A. W. and Rigdon, R. H. (1945). J. Lab. clin. Med., 30, 327.

Frost, D. V., Elvehjem, C. A. and Hart, E. B. (1941). J. Nutr., 21, 93. Gall, L. S., Smith, S. E., Becker, D. E., Stark, C. N. and Loosli, J. K. (1949). Science, 109, 468.

Gubler, C. J., Cartwright, G. E. and Wintrobe, M. M. (1950). J. biol. Chem., 184, 575.

Herz, O. (1928). Mschr. Kinderheilk., 40, 1.

Josephs, H. W. (1936). Medicine, 15, 307.

Kato, K. (1937). J. Pediat., 11, 385.

and Iob, V. (1940). Amer. J. clin. Path., 10, 751

Landé, L. (1919). Z. Kinderheilk.

Lichtenstein, A. (1921). Acta paediat. Uppsala, 1, 194.
and Nordenson, N. G. (1939). Folia haemat., Lpz., 63, 155.

Mackay, H. M. M. (1931). Spec. Rep. Ser. med. Res. Coun. Lond., No. 159.

(1935). Archives of Disease in Childhood, 10, 195.

Merritt, K. K. and Davidson, L. T. (1934). Amer. J. Dis. Child., 47, 261 .

Orten, J. M. (1936). Amer. J. Physiol., 114, 414

and Bucciero, M. C. (1948). J.'biol. Chem., 176, 961.

-, Underhill, F. A., Mugrage, E. R. and Lewis, R. C. (1932) Ibid., 96, 11 .

Parsons, L. G. and Hawksley, J. C. (1933). Archives of Disease in Childhood, 8, 117 .

Robinson, J. C., James, G. W. and Kark, R. M. (1949). New Engl. Med. J., 240, 749.

Shen, S. C. and Homburger, F. (1951). J. Lab. clin. Med., 37, 182.

Snelling, C. E. (1933). J. Pediat., 2, 546.

Stanley, A. J., Hopps, H. C. and Hellbaum, A. A. (1946). Proc. Soc. exp. Biol., N.Y., 61, 130 .

Vaughan, J. (1948). Brit. med. J., 1, 35.

Virdis, S. (1952). Pediatria (Napoli), 60, no. 5-6, p. 302.

Waltner, K. (1930). Acta paediat., Uppsala, 11, 438.

Whitby, L. and Britton, C. J. C. (1950). Disorders of the Blood, p. 627, 6 th ed. London.

Wintrobe M. M. Grinstein, M., Dubash, J. J., Humphreys, S. R. Ashenbrucker, H. and Worth, W. (1947). Blood, 2, 323 . 